\section{PENGEMBANGAN KURIKULUM PENDIDIKAN}

\section{INDONESIA}

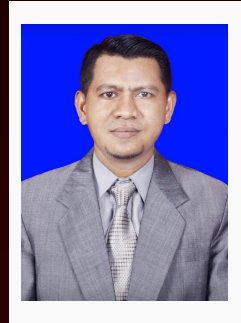

Zulkifli, merupakan dosen pendidik di Universitas Muhammadiyah Tanggerang dan Universitas Islam Negeri Syarif Hidayatullah Jakarta. Lahir di Kota Jakarta, 02 Juli 1978. Pendidikan akhir pada Program Pasca Sarjana S3 bidang Pendidikan Islam.

Pendidikan dapat diartikan sebagai suatu proses pertumbuhan individu yang berlangsung sepanjang masa. Berkaitan dalam konsep pendidikan seumur hidup yang sangat penting dan tidak dapat dipisahkan dengan interaksi manusia. Sehingga, konsekuensinya harus dilaksanakan dengan sebaik-baiknya untuk memperoleh hasil yang diharapkan. Perkembangan zaman yang terus berkembang dapat merubah keadaan sosial, ekonomi, budaya bahkan pola fikir masyarakat, maka atas dasar itulah pengembangan kurikulum merupakan keniscayaan bagi institusi pendidikan agar proses dan hasil pendidikan tidak menyimpang dengan harapan mampu menjawab kebutuhan masyarakat sesuai tuntutan zaman. Dalam hal ini para pakar pendidikan berusaha meramu sebuah kurikulum yang tepat, karena salah satu komponen pendidikan yang menjadi tolak ukur dan ruhnya adalah kurikulum dalam keberhasilan pendidikan di sebuah negara.

Secara tidak langsung semakin maju peradaban suatu masyarakat akan semakin bertambah banyak masalah yang harus dihadapi, termasuk dalam bidang pendidikan. Mulai tahun pelajaran 2013/2014, pemerintah telah memberlakukan kurikulum baru yang disebut dengan kurikulum 2013 pada beberapa sekolah sasaran sebagai piloting project. Dalam buku ini membahas mengenai perjalanan sejarah kurikulum pendidikan nasional sejak tahun 1945 yang telah mengalami perubahan, yaitu pada tahun 1947,1952, 才964, 1968, 1975, 1984, 1994, 1999, 2004, dan 2006.

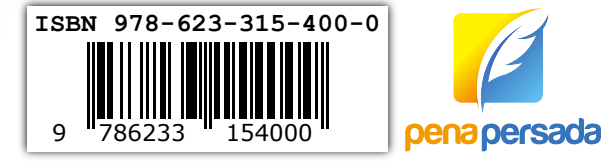

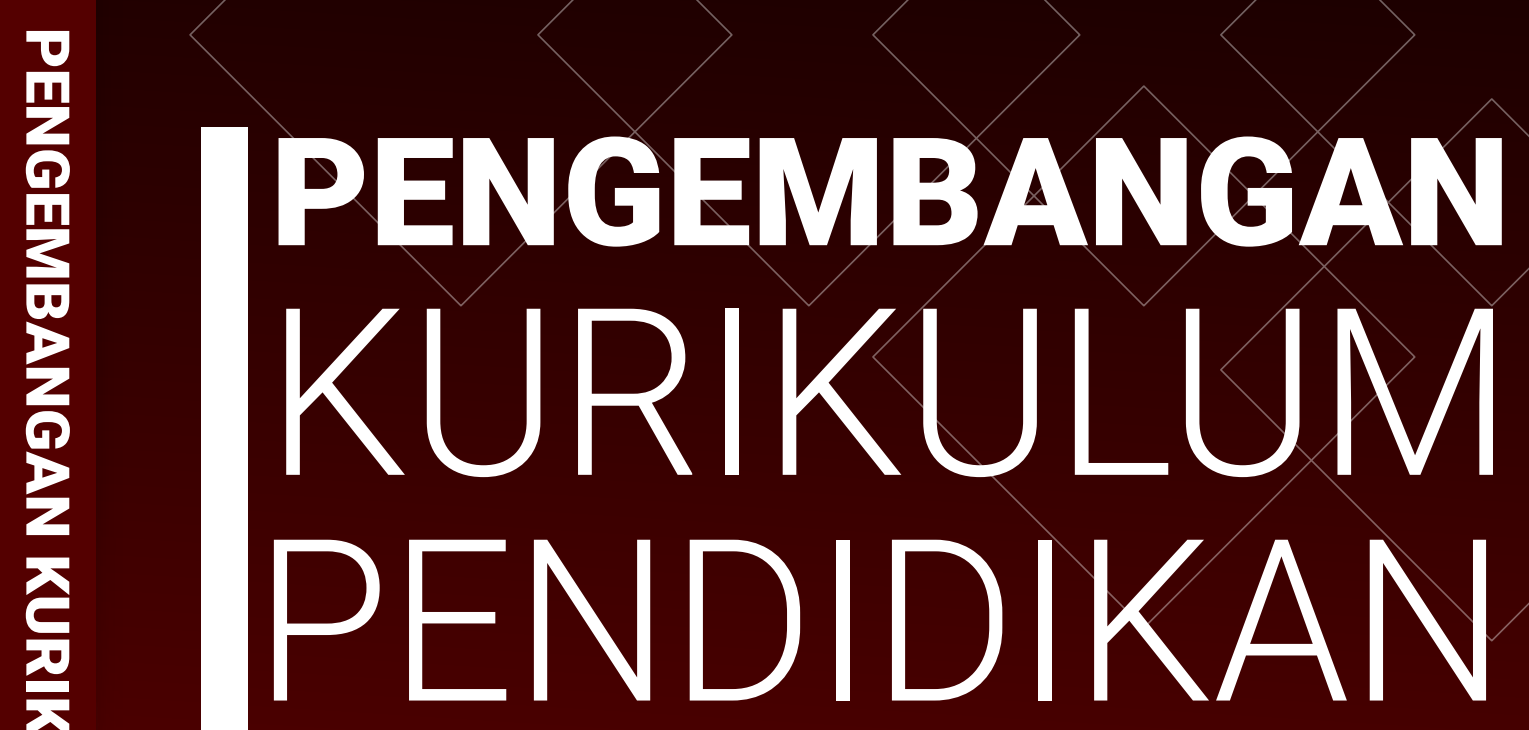

DI INDONESIA

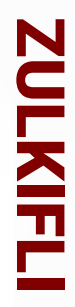

ZULKIFLI

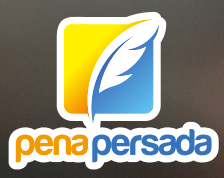




\title{
PENGEMBANGAN KURIKULUM PENDIDIKAN DI INDONESIA
}

\author{
ZULKIFLI
}

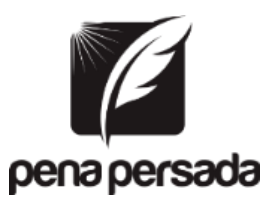

PENERBIT CV. PENA PERSADA 


\section{PENGEMBANGAN KURIKULUM PENDIDIKAN \\ DI INDONESIA}

Penulis:

Zulkifli

ISBN : 978-623-315-400-0

Editor:

Wiwit Kurniawan

Design Cover :

Retnani Nur Briliant

Layout :

Eka Safitry

\section{Penerbit CV. Pena Persada}

Redaksi :

Jl. Gerilya No. 292 Purwokerto Selatan, Kab. Banyumas

Jawa Tengah

Email : penerbit.penapersada@gmail.com

Website : penapersada.com Phone : (0281) 7771388

Anggota IKAPI

All right reserved

Cetakan pertama : 2021

Hak Cipta dilindungi oleh undang-undang. Dilarang memperbanyak karya tulis ini dalam bentuk apapun tanpa izin penerbit 


\section{KATA PENGANTAR}

Segala puji senantiasa kita panjatkan kehadirat Allah SWT, atas segala rahmat dan karunianya, akhirnya penulis dapat menyelesaikan penyusunan buku yang berjudul "PENGEMBANGAN KURIKULUM PENDIDIKAN DI INDONESIA". Saya menyadari bahwa tanpa bantuan dan bimbingan dari berbagai pihak sangatlah sulit bagi saya untuk menyelesaikan karya ini. Oleh karena itu, saya mengucapkan banyak terima kasih pada semua pihak yang telah membantu penyusunan buku ini. Sehingga buku ini bisa hadir di hadapan pembaca.

Pendidikan nasional berfungsi mengembangkan kemampuan dan membentuk watak serta peradaban bangsa yang bermartabat dalam rangka mencerdaskan kehidupan bangsa, bertujuan untuk berkembangnya potensi peserta didik agar menjadi manusia yang beriman dan bertaqwa kepada Tuhan Yang Maha Esa, berkahlaq mulia, sehat, berilmu, cakap, kreatif, mandiri dan menjadi warga negara yang demokratis serta bertanggung jawab. Secara tidak langsung semakin maju peradaban suatu masyarakat akan semakin bertambah banyak masalah yang harus dihadapi, termasuk dalam bidang pendidikan. Mulai tahun pelajaran 2013/2014, pemerintah telah memberlakukan kurikulum baru yang disebut dengan kurikulum 2013 pada beberapa 
sekolah sasaran sebagai piloting project. Dalam buku ini membahas mengenai perjalanan sejarah kurikulum pendidikan nasional sejak tahun 1945 yang telah mengalami perubahan, yaitu pada tahun 1947,1952, 1964, 1968, 1975, 1984, 1994, 1999, 2004, dan 2006.

Penulis menyadari bahwa buku ini masih jauh dari kesempurnaan. Oleh karena itu kritik dan saran yang membangun sangat dibutuhkan guna penyempurnaan buku ini. Akhir kata saya berharap Allah SWT berkenan membalas segala kebaikan semua pihak yang telah membantu.

Penulis 


\section{DAFTAR ISI}

KATA PENGANTAR ..............................................................iii

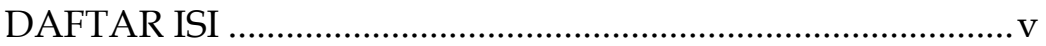

BAB I PENDAHULUAN ........................................................... 1

A. Sistem Pendidikan di Indonesia ............................... 1

B. Kurikulum Pendidikan Nasional................................. 9

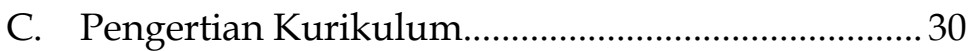

BAB II KURIKULUM RENCANA PELAJARAN (1947-

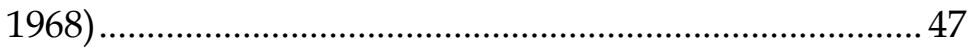

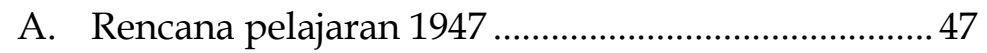

B. Kurikulum Rencana Pendidikan 1964 ..................... 48

C. Kurikulum 1968........................................................ 50

BAB III KURIKULUM BERORIENTASI PENCAPAIAN

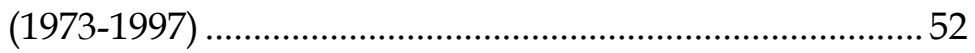

A. Kurikulum 1973...................................................... 52

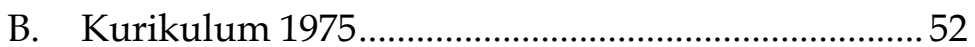

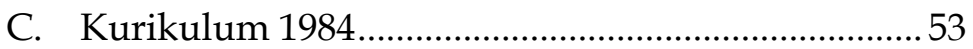

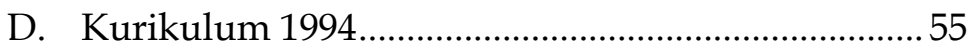

E. Kurikulum 1997 ............................................................ 57

BAB IV KURIKULUM BERBASIS KOMPETENSI (2004-

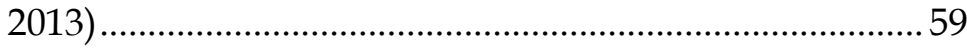

A. Kurikulum Berbasis Kompetensi (KBK) 2004 ......... 60 
B. Kurikulum Tingkat Satuan Pendidikan (KTSP) 2006.

C. Kurikulum 2013 (K13)

BAB V UPAYA MENEMUKAN KURIKULUM PENDIDIKAN ISLAM YANG IDEAL 65

A. Menggunakan Strategi Kurikulum yang Tepat......65

B. Menggunakan Muatan Materi IPTEK Sesuai dengan Tantangan Zaman

C. Muatan Materi IMTAQ Berorientasi pada Ajaran

Kenabian. .73

D. Contoh Rekomendasi Kurikulum Pendidikan Islam .77

1. Kurikulum Sekolah Dasar (SD) ........................77

2. Kurikulum Sekolah Menengah Pertama

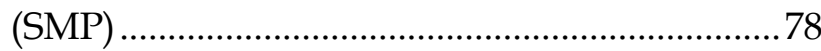

3. Kurikulum Sekolah Menengah Atas (SMA)....80

4. Kurikulum Perguruan Tinggi............................... 81

5. Mengenal Pelaksanaan Kurikulum 2013...........88

6. Sistem Evaluasi dalam Kurikulum 2013 .......... 91

7. Karakteristik Kurikulum 2013 ........................... 92

8. Posisi Guru dalam Situasi Kurikulum yang

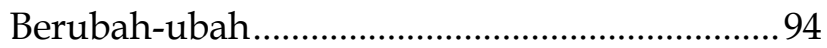

9. Berbasis Penelitian.............................................. 102

10. Kepribadian Guru yang Diinginkan................105

11. Proses Pembelajaran Kurikulum 2013 ............. 108 
12. Prinsip Pengembangan Kurikulum 2013 ....... 109

13. Implikasi Kurikulum 2013 bagi Guru SD/MI112

14. Tahap Persiapan Pelaksanaan ........................... 115

15. Kerangka Kerja Kurikulum 2013......................120

16. Kelebihan dan Kelemahan kurikulum 2013 .. 127

17. Konsep Dasar Pembelajaran dalam Kurikulum 2013 _...............................................129

18. Metode Pembelajaran dalam Kurikulum 2013

19. Model Pembelajaran dalam Kurikulum 2013134

20. Perbedaan Kurikulum 2013 dan KTSP 135

E. Pengembangan Kurikulum 159

F. Landasan Pengembangan Kurikulum 162

1. Landasan Agama................................................ 163

2. Landasan Filosofis............................................... 164

3. Landasan Psikologis ........................................... 165

4. Landasan Sosial Budaya.....................................166

G. Prinsip-Prinsip Pengembangan Kurikulum...........167

H. Pendekatan Pengembangan Kurikulum.................168

I. Pendekatan Subyek Akademik ................................169

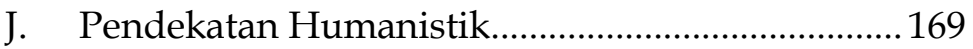

K. Pendekatan Kurikulum Rekonstruksi Sosial ........170

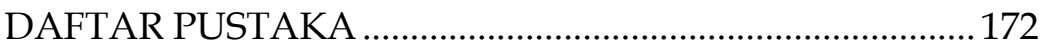




\section{PENGEMBANGAN KURIKULUM PENDIDIKAN DI INDONESIA}




\section{BAB I \\ PENDAHULUAN}

\section{A. Sistem Pendidikan di Indonesia}

Pendidikan adalah salah satu wadah atau tempat berisi suatu proses belajar mengajar yang diartikan sebagai suatu rangkaian interaksi antara siswa dan guru dalam mencapai tujuan ${ }^{1}$. Pendidikan juga diartikan sebagai suatu proses pertumbuhan individu yang berlangsung sepanjang masa. Berkaitan dalam konsep pendidikan seumur hidup yang sangat penting dan tidak dapat dipisahkan dengan interaksi manusia. Sehingga, konsekuensinya harus dilaksanakan dengan sebaik-baiknya untuk memperoleh hasil yang diharapkan. Pendidikan adalah alat atau sarana bagi setiap manusia untuk mengembangkan keilmuan dan pengetahuan, oleh karena itu pendidikan diharapkan memiliki konsep pendidikan dan dasar-dasar yang tertata, dan memiliki etika.

Aktivitas pendidikan baik dalam penyusunan konsep teoritis maupun dalam pelaksanaan operasionalnya harus memiliki dasar yang kokoh

Tri Rizqi Ariantoro, Dampak Game Online Terhadap Prestasi Belajar Pelajar, Jutim, Vol 1, No. 1, Desember (2016) 
dengan berpedoman kepada etika akademis². Dewasa ini, tantangan pendidikan dalam hal ini adalah yang dihadapi oleh para peserta didik di dalam dan diseluruh dunia pendidikan termasuk di dalam lingkungan pesantren tengah menghadapi tantangan serius. ${ }^{3}$

Salah satu komponen penting pada lembaga pendidikan formal yang digunakan sebagai acuan untuk menentukan isi pengajaran, mengarahkan proses mekanisme pendidikan, tolok-ukur keberhasilan dan kualitas hasil pendidikan, adalah kurikulum.4 Kurikulum adalah program pendidikan yang disediakan oleh lembaga pendidikan bagi siswa. Berdasarkan program lembaga pendidikan tersebut siswa melakukan berbagai kegiatan belajar, sehingga

Mursal Aziz, Etika Akademis Dalam Pendidikan Islam, Jurnal Tarbiyah, Vol. 25, No. 1, Januari-Juli (2018)

QS. Al-Qashash ayat 77: "Dan carilah apa yang telah dianugerahkan Allah kepadamu (kebahagiaan ) negeri akhirat, dan janganlah kamu melupakan kebahagiannmu dari (kenikmatan) duniawi dan berbuat baiklah kepada orang lain sebagaimana Allah telah berbuat baik kepadamu". Soenarjo, AlQur'an dan Terjemahnya ( Jakarta: Depag RI, 2015), 623. Secara implisit, ayat ini menekankan kepada proses pendidikan yang menitikberatkan kepada dua persoalan yang sangat penting secara berimbang, yakni pembinaan, pengajaran, pelatihan dalam aspek jasmani dan pembinaan dan pembangunan ruhiyah atau jiwa. Bagi Islam, dua aspek penting ini merupakan sebuah kesatuan yang harus diusung secara bersama-sama untuk menumbuhkan dan mengembangkan potensi manusia dalam mencapai kesehjateraan material dan non-material. Kesehjateraan material harus menjadi pengantar kesehjateraan abadi yakni kehidupan di alam baka. Tidaklah Qur'ani bila pendidikan hanya berorientasi atau mengaksentuasikan usahanya pada menumbuh kembangkan aspek jasmani, sementara aspek rohani ditinggalkan. Ahmad Tafsir, Filsafat Pendidikan Islami, (Bandung: Rosdakarya, 2006), cet. Ke-1, 33 
mendorong perkembangan dan pertumbuhannya sesuai dengan tujuan pendidikan yang telah ditetapkan.

Pendidikan nasional berfungsi mengembangkan kemampuan dan membentuk watak serta peradaban bangsa yang bermartabat dalam rangka mencerdaskan kehidupan bangsa, bertujuan untuk berkembangnya potensi peserta didik agar menjadi manusia yang beriman dan bertaqwa kepada Tuhan Yang Maha Esa, berakhlak mulia, sehat, berilmu, cakap, kreatif, mandiri dan menjadi warga negara yang demokratis serta bertanggung jawab. 5 Secara tidak langsung semakin maju peradaban suatu masyarakat akan semakin bertambah banyak masalah yang harus dihadapi, termasuk dalam bidang pendidikan. Permasalahan pendidikan adalah amat banyak, antara satu masalah dengan masalah yang lain mempunyai hubungan yang kompleks di Indonesia dibandingkan dengan permasalahan pendidikan. Kompleksitas permasalahan pendidikan itu muncul tidak saja karena tuntutan perubahan internal dalam skala nasional bahkan skala lokal. ${ }^{6}$ Permasalahan tersebut menjadi tanggung jawab pendidikan terlihat kondisi sekolah sekarang ini nampaknya sudah terealisasi dengan semakin banyak

Lukmanul Hakim, Perencanaan Pembelajaran, (Bandung: CV. Wacana Prima, 2009), 92

Ali Rohmat, Kapita Selekta Pendidikan, (Yogyakarta, Penerbit Teras, 2004), 3-4 
siswa yang disibukkan dengan media sosial yang hadir sebagai dampak dari globalisasi. Salah satu dampak dari penggunaan full time mereka terhadap gadjet yang seluruh aplikasinya berisi sosial media dan browser dengan adanya generasi yang lebih suka mencari jawaban dari internet dari pada berdiskusi untuk memecahkan sebuah permasalahan. Jika hal tersebut berlanjut tanpa adanya filter yang kuat dari pendidikan maka akibat yang ditimbulkan hanyalah dampak negatif. Dengan istilah lain ialah lahirnya handphone yang smart dan manusia yang bodoh atau idiot. Semua bentuk permasalahan pendidikan yang ada seolah membuat akademisi menjadi geram dan mulai mencari cara agar pendidikan Indonesia bangkit dan membawa Indonesia pada pemecahan masalah pendidikan yang continues dan berharap hingga sampailah negara Indonesia pada fase dimana Indonesia membuat kebijakan untuk mengganti kurikulum, memberi subsidi besar-besaran dalam pendidikan atau bahkan meningkatkan kesejahteraan guru sebagai pemangku utama pendidikan. Meskipun telah berkali-kali Indonesia mencari konsep pendidikan melalui merubah kurikulum dan menetapkan berbagai kebijakan. Akan tetapi akan menjadi sia-sia ketika guru sebagai penopang utama pendidikan tetap menggunakan pola 
lama dalam pembelajarannya. Bahwa konsep pendidikan di Indonesia hanya akan menghasilkan output yang cerdas secara akademik dan kognitif tetapi nihil di afektif dan psikomotorik.

Cara yang seperti ini dijelaskan oleh Paulo Freire bahwa dalam hal ini pendidikan masih mengikuti sistem "gaya bank", yakni guru mengajar murid diajar, guru mengetahui segala sesuatu murid tidak tahu apaapa, guru berfikir murid dipikirkan, guru bercerita murid patuh mendengarkan, guru menentukan peraturan murid diatur, guru memilih dan memaksakan pilihannya murid menyetujuinya, guru adalah subjek dalam belajar dan murid adalah objek belaka.7 Dalam konsep pendidikan lama situasi pembelajaran didominasi oleh guru. Siswa lebih bersifat pasif menerima sepenuhnya materi apa saja yang disampaikan dan diberikan guru. Kurikulum, mutlak direncanakan, disusun dan dibuat oleh pemerintah dan guru atau sekolah tanpa mengikutsertakan siswa. Terkait dengan hal tersebut berdasarkan studi psikologi dan sosiologi pendidikan, masyarakat pendidikan umumnya menghendaki perubahan dan hendaknya konsep pendidikan terutama dalam pengajaran agar

Paulo Freire, Pendidikan Kaum Tertindas, (Jakarta: LP3S, 1985), 51-52 
lebih memperhatikan minat, kebutuhan dan kesiapan siswa untuk belajar. ${ }^{8}$

Berdasarkan tujuan tersebut Pemerintah Indonesia memiliki tanggung jawab mewujudkan masyarakat Indonesia menjadi masyarakat yang berkualitas. Pendidikan nasional bukan hanya sebatas peningkatan kualitas kehidupan namun pendidikan juga meningkatkan harkat dan martabat seseorang, maka seharusnya pendidikan dimulai dari sedini mungkin dalam mencetak generasi yang sholeh dan sholeha, jangan sampai menyengsarakan dan menelantarkan anak. Sebagaimana Allah mengingatkan manusia dalam firmannya surah An-Nisa surat 04 :9.9

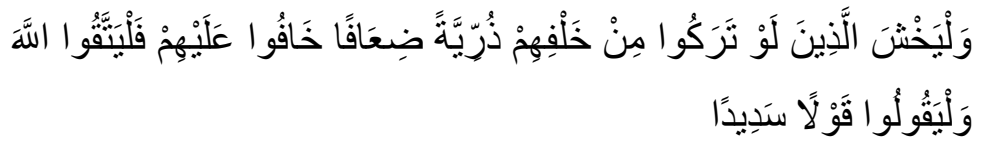

“Dan hendaklah takut kepada Allah orang-orang yang seandainya meninggalkan dibelakang mereka anak-anak yang lemah, yang mereka khawatir terhadap (kesejahteraan) mereka. oleh sebab itu hendaklah mereka bertakwa kepada Allah dan hendaklah mereka mengucapkan perkataan yang benar." 
Perkembangan zaman yang terus berkembang dapat merubah keadaan sosial, ekonomi, budaya bahkan pola pikir masyarakat, maka atas dasar itulah pengembangan kurikulum merupakan keniscayaan bagi institusi pendidikan agar proses dan hasil pendidikan tidak menyimpang dengan harapan mampu menjawab kebutuhan masyarakat sesuai tuntutan zaman. Permasalahan dan pengembangan serta kehidupan manusia terus berkembang pesat ketika bersentuhan dengan ilmu pengetahuan dan teknologi. Dalam hal ini para pakar pendidikan berusaha meramu sebuah kurikulum yang tepat, karena salah satu komponen pendidikan yang menjadi tolak ukur dan ruhnya adalah kurikulum dalam keberhasilan pendidikan di sebuah negara. ${ }^{10}$ Dalam proses pengembangan kurikulum, banyak sekali masalah yang dihadapi, yang memerlukan pertimbangan dan pemecahan tersendiri. Semua masalah tersebut disebabkan oleh berbagai kondisi yang ada, yang disesuaikan dengan tuntutan dan prinsip kebutuhan yang perlu dipahami. Berbagai masalah yang termasuk dalam masalah umum dapat dikelompokkan menjadi delapan kelompok, yaitu bidang cakupan (skope), relevansi, keseimbangan, integrasi, sekuens, 
kontinuitas, artikulasi, dan kemampuan transfer (transfer ability)11.

Pengembangan kurikulum harus dilandasi oleh manajemen berdasarkan pertimbangan-pertimbangan multidimensional, sebagai berikut.

1. Manajemen sebagai suatu disiplin ilmu sangat erat kaitannya dengan disiplin ilmu-ilmu lainnya, seperti filsafat, psikologi, sosial budaya, sosial teknologi.

2. Para pengembang kurikulum mengikuti pola pikir yang sinkron dengan pola dan struktur berfikir dalam manajemen.

3. Implementasi kurikulum sebagai bagian integral dalam pengembangan kurikulum membutuhkan konsep-konsep, prinsip-prinsip, dan prosedur serta pendekatan manajemen.

4. Pengembangan kurikulum tidak lepas dari kebijakan di bidang pendidikan, yang bersumber dari kebijakan pendidikan nasional.

5. Kebutuhan manajemen di sektor bisnis dan industri.

Dalam pengembangan kurikulum, banyak hal yang harus diperhatikan dan dipertimbangkan sebelum mengambil suatu keputusan. Setiap jenis kurikulumnya, pasti memerlukan asas-asas yang harus dipegang. Asas-asas tersebut cukup kompleks dan tidak

Oemar Hamalik, Manajemen Pengembangan Kurikulum, (Bandung: Rosdakarya, 2006), 5 
jarang memiliki hal-hal yang bertentangan sehingga memerlukan seleksi. Falsafah yang berlainan, bersifat otoriter, demokrasi, sekuler atau religius, akan memberikan warna yang berbeda dengan kurikulum yang dimiliki oleh bangsa yang bersangkutan. Begitu juga apabila dilihat dari perbedaan masyarakat, organisasi bahan yang digunakan dan pilihan psikologi belajar dalam mengembangkan kurikulum tersebut. Secara tidak langsung pengembangan kurikulum harus berasaskan kepada asas filosofis, asas sosiologis, asas psikologis, asas organisatoris.

\section{B. Kurikulum Pendidikan Nasional}

Kurikulum merupakan salah satu unsur yang memberikan kontribusi paling signifikan terhadap proses berkembangnya kualitas potensi peserta didik. Mulai tahun pelajaran 2013/2014, pemerintah telah memberlakukan kurikulum baru yang disebut dengan kurikulum 2013 pada beberapa sekolah sasaran sebagai piloting project. Implementasi kurikulum 2013 didasarkan kepada tantangan internal dan eksternal. Dengan demikian kurikulum 2013 dirancang dengan maksud untuk mempersiapkan insan Indonesia supaya mereka memiliki kemampuan hidup sebagai pribadi dan warganegara yang beriman, produktif, kreatif, 
inovatif, dan afektif serta mampu berkontribusi kepada kehidupan bermasyarakat, berbangsa, bernegara dan peradaban dunia. Namun demikian, kurikulum seringkali tidak mampu mengikuti kecepatan laju perkembangan masyarakat. Oleh karena itu, pengembangan dan pembenahan kurikulum harus senantiasa dilakukan secara berkesinambungan. Sejak zaman kemerdekaan, kurikulum pendidikan di Indonesia juga senantiasa berubah.

Dalam perjalanan sejarah sejak tahun 1945, kurikulum pendidikan nasional telah mengalami perubahan, yaitu pada tahun 1947,1952, 1964, 1968, 1975, 1984, 1994, 1999, 2004, dan 2006. (Rohman 2012) Perubahan tersebut merupakan konsekuensi logis dari terjadinya perubahan sistem politik, sosial budaya, ekonomi, dan iptek dalam masyarakat berbangsa dan bernegara. Sebab, kurikulum sebagai perangkat rencana pendidikan perlu dikembangkan secara dinamis sesuai dengan tuntutan dan perubahan yang terjadi di masyarakat.

Semua kurikulum nasional dirancang berdasarkan landasan yang sama, yaitu Pancasila dan UUD 1945, perbedaannya pada penekanan pokok dari tujuan pendidikan serta pendekatan dalam merealisasikannya. Setelah Indonesia merdeka dalam pendidikan dikenal 
beberapa masa pemberlakuan kurikulum yaitu kurikulum sederhana (1974-1964), pembaharuan kurikulum (1968 dan 1975), Kurikulum Berbasis Keterampilan Proses (1984 dan 1994), dan kurikulum Berbasis Kompetensi (2004 dan 2006) yang disempurnakan menjadi Kurikulum Tingkat Satuan Pendidikan (KTSP). Kurikulum 2013 merupakan penyempurnaan dari KTSP agar pendidikan di Indonesia mampu mengikuti perkembangan dan tuntutan zaman. Pengembangan kurikulum adalah istilah yang komprehensif, di dalamnya mencakup perencanaan, penerapan dan evaluasi. Dalam konteks pendidikan di pesantren, menurut Nurcholish Madjid, istilah kurikulum tidak dikenal di dunia pesantren, terutama masa pra kemerdekaan, walaupun sebenarnya materi pendidikan sudah ada dan keterampilan itu ada dan diajarkan di pesantren. Kebanyakan pesantren tidak merumuskan dasar dan tujuan pesantren secara eksplisit dalam bentuk kurikulum. Tujuan pendidikan pesantren ditentukan oleh kebijakan Kyai, sesuai dengan perkembangan pesantren tersebut. ${ }^{12}$

Dewasa ini pesantren dihadapkan pada banyak tantangan termasuk di dalamnya modernisasi pendidikan Islam. Dalam banyak hal, sistem dan

12 Nurcholish Madjid, Bilik-Bilik Pesantren Sebuah Potret Perjalanan (Jakarta: Paramadina, 1997), 59 